\title{
PERBANDINGAN RESILIENCE CONCEPT DAN RULE-BASED TERHADAP PENANGANAN JADWAL OPERASI BEDAH UNTUK EMERGENCY CASE DAN ELECTIVE SURGERY
}

\author{
${ }^{1,2}$ Nurmaya, ${ }^{1,2}$ Herika Hayurani, ${ }^{1}$ Muhammad Al Ziqri, ${ }^{1,2}$ Nova Eka Diana, ${ }^{3}$ Lisa Wiyartanti \\ ${ }^{1}$ Program Studi Teknik Informatika, Fakultas Teknologi Informasi, Universitas YARSI, Jakarta, Indonesia \\ ${ }^{2}$ YARSI E-Health Research Center (YEHRC) \\ ${ }^{3}$ Center for Bionics, Korea Institute of Science and Technology, Seoul, 136-791, Korea \\ E-mail: nurmaya@yarsi.ac.id
}

\begin{abstract}
Surgical schedule changes, caused by uncertainty case on the day of operation, can decrease the hospital's service quality. Resilience Concept algorithm produces the risk value for schedule modification caused by the uncertainty case. However, this algorithm only managed the delay of elective surgery in previous research. Therefore, this study applies the resilience concept algorithm in handling the emergency case, and the shift of elective surgery into earlier than its current schedule. Resilience algorithm's performance is compared to Rule-Based algorithm in managing the surgery's schedule for uncertainty case. There are 20 test scenarios, consisting of 12 scenarios for elective surgery schedule changes and 8 scenarios for emergency case, that were given trial to the algorithms. Both of the algorithms $100 \%$ succeeded passing through all the scenarios. Yet, both of the algorithms could not give the priority schedule changes based on the risk level. Resilience algorithm could not give the priority based on the risk level of value caused by the imperfection of the resources delay calculation $\left(T_{n}\right)$.
\end{abstract}

Keywords: Surgical schedule, Resilience Concept, Rule-Based, Uncertainty Case, Emergency Case

\begin{abstract}
Abstrak
Perubahan jadwal operasi akibat kejadian tidak terduga (uncertainty case) di hari-H operasi dapat menurunkan kualitas layanan rumah sakit. Algoritma Resilience Concept menghasilkan nilai resiko untuk setiap perubahan jadwal operasi yang terjadi akibat uncertainty case. Namun, algoritma ini hanya mengelola perubahan jadwal akibat keterlambatan penyelesaian operasi elektif, yang merupakan salah satu uncertainty case, pada penelitian sebelumnya. Oleh karena itu, penelitian ini menerapkan algoritma resilience concept dalam menangani kasus gawat darurat (emergency case), dan perubahan waktu pelaksanaan operasi elektif menjadi lebih awal. Kinerja algoritma resilience concept dibandingkan dengan algoritma rule-based dalam mengelola jadwal operasi untuk uncertainty case. Terdapat 20 skenario pengujian diujicobakan kepada kedua algoritma, yang terdiri dari 12 skenario pengujian perubahan jadwal operasi elektif dan 8 skenario emergency case . Kedua algoritma $100 \%$ berhasil mengeksekusi semua skenario pengujian. Akan tetapi, keduanya belum dapat memberikan prioritas perubahan jadwal berdasarkan tingkatan resiko. Ketidakoptimalan perhitungan waktu keterlambatan sumber daya $\left(T_{n}\right)$ menjadi penyebab algoritma Resilience belum dapat memberikan prioritas solusi berdasarkan nilai resiko yang dihasilkan.
\end{abstract}

Kata Kunci: Jadwal Operasi, Resilience Concept, Rule-Based, Uncertainty Case, Emergency Case.

\section{Pendahuluan}

Penjadwalan operasi bedah merupakan salah satu komponen penting dalam pelayanan sebuah rumah sakit. Waktu tunggu yang lama dalam mendapatkan tindakan operasi bedah dapat menurunkan kualitas layanan rumah sakit. Salah satu faktor yang mempengaruhi waktu tunggu 
adalah kejadian yang tidak terduga pada hari pelaksanaan operasi (hari-H operasi) yang disebut juga uncertainty case. Kasus gawat darurat, keterlambatan dalam pelaksanaan maupun penyelesaian operasi elective termasuk dalam uncertainty case yang terjadi di hari-H operasi. Perubahan jadwal dapat memberikan dampak negatif bagi pasien dan rumah sakit. Resiko tinggi pada kesehatan pasien serta biaya yang dihabiskan merupakan efek buruk yang harus dihindari ketika terjadi perubahan jadwal. Oleh sebab itu, meminimalisir efek negatif sangat diharuskan ketika melakukan perubahan jadwal operasi.

Penerapan algoritma stochastic, linier programming dilakukan di penelitian sebelumnya dalam mengatur jadwal operasi bedah untuk uncertainty case. Namun, penelitian sebelumnya hanya mempertimbangkan kasus gawat darurat sebagai uncertainty case (Hans et al. 2008; Lamir et al. 2008a). Solusi yang diberikan hanya efektif pada penanganan perubahan jadwal operasi bedah elective dibandingkan perubahan jadwal yang terjadi di hari-H operasi. Hal ini dikarenakan durasi pelaksanaan tindakan bedah sudah ditentukan.

Wiyartanti et al. (2015) membuat sebuah rumus penjadwalan untuk mengelola penjadwalan operasi bedah untuk uncertainty case di hari-H Operasi dengan menggunakan konsep resilience. Pengelolaan penjadwalan dengan meminimalkan efek negatif adalah tujuan dari algoritma tersebut. Namun, simulasi pengaturan operasi bedah untuk kasus gawat darurat (emergency case) belum dilakukan.

Waktu keterlambatan sumber daya operasi X , yang disebabkan penambahan durasi pelaksanaan operasi bedah $\mathrm{Y}$, mempengaruhi nilai ketersediaan sumber daya operasi X. Ketersediaan sumber daya $X$ mempengaruhi nilai resiko yang dihasilkan atas penambahan waktu pelaksanaan operasi Y. Akan tetapi, pengujian terhadap kasus pergeseran waktu pelaksanaan operasi Y menjadi lebih awal belum dilakukan. Tujuan dari penelitian ini adalah melakukan pengujian algoritma penjadwalan resilience concept dalam menangani jadwal operasi bedah untuk emergency case, dan jadwal pelaksanaan operasi elektif yang dimajukan lebih awal. Perbandingan kinerja dilakukan antara algoritma resilience dengan algoritma rule-based dalam menangani penjadwalan operasi bedah uncertainty case.

Penerapan rule-based dalam bidang kesehatan telah banyak diaplikasikan. Saraiva et al. (2015) menggunakan rule-based reasoning dalam mendiagnosa penyakit kanker. Sebuah metode caching yaitu Profit SACC, yang digunakan untuk meningkatkan kemampuan pencarian data $e$-health secara real time antara lain data rekam medis dalam bentuk gambar dan video, dibangun berdasarkan rule-based (Haraty 2015).

Rule-based bekerja sangat efesien terhadap data deterministik. Kondisi pasien serta ketersediaan sumber daya menjadi nilai mutlak dalam mengatur penjadwalan operasi bedah. Kondisi pasien yang memiliki status gawat darurat menjadi prioritas pertama dalam pengaturan jadwal operasi bedah (Dexter, Willemsen \& Lee 2007). Sumber daya adalah ruang operasi, perangkat, dan tim bedah yang berstatus tersedia, dapat digunakan, dan tidak sedang melakukan operasi di waktu tersebut.

\subsection{Algoritma Penjadwalan berbasis Resilience Concept}

Resilience dapat digambarkan sebagai kemampuan mencegah dan menanggulangi kondisi buruk baik yang belum dan sudah terjadi (Hollnagel, Wood \& Leveson 2006). Beberapa studi menerapkan teori resilience di bidang kesehatan. Jeffcott et al. (2009) mengaplikasikan konsep resilience dalam penyelesaian kasus klinis yang berhubungan dengan keselamatan pasien. Resilience checklist didefinisikan untuk mengidentifikasi terjadinya suatu resiko atau bahaya (Carthey De 2001).

Wiyartanti et al. (2015) menerapkan resilience concept dalam membangun algoritma penjadwalan kegiatan operasi bedah untuk Uncertainty Case. Tabel 1 menunjukkan tiga dimensi ketidakpastian yang disebabkan oleh gangguan waktu pada jadwal operasi bedah.

Persamaan (1) adalah rumus menghitung nilai resiko terhadap perubahan jadwal operasi bedah berdasarkan dimensi ketidakpastian.

Tabel 1 - Dimensi Ketidakpastian Penjadwalan Ruang Operasi (Wiyartanti et al, 2015)

\begin{tabular}{ll}
\hline Dimensi & Deskripsi \\
\hline $\begin{array}{l}\text { Condition } \\
\text { Compliance }\end{array}$ & $\begin{array}{l}\text { Kondisi terakhir pasien yang } \\
\text { merupakan prioritas penting dalam } \\
\text { pengambilan keputusan pada } \\
\text { penjadwalan. }\end{array}$ \\
$\begin{array}{l}\text { Resources } \\
\text { Availability }\end{array}$ & $\begin{array}{l}\text { Keberadaan sumber daya seperti } \\
\text { ruang operasi, perangkat bedah, dan } \\
\text { staf medis (anestesi, dokter bedah, } \\
\text { perawat). }\end{array}$ \\
Change Consent & $\begin{array}{l}\text { Persetujuan dari stakeholder, yang } \\
\text { terkena dampak perubahan jadwal } \\
\text { operasi bedah seperti staf, pasien dan }\end{array}$ \\
\hline
\end{tabular}


keluarga, terhadap perubahan jadwal baru.

$$
E_{Y}=C_{P}+A_{X}+C_{O}
$$

$E_{Y}$ adalah nilai resiko pada perubahan jadwal operasi Y. Nilai berasal dari hasil penjumlahan dimensi atau variabel uncertainty diantaranya kondisi pasien $\left(C_{P}\right)$, ketersediaan sumber daya $\left(A_{X}\right)$ dan persetujuan pasien maupun pihak rumah sakit $\left(C_{O}\right) . A_{X}$ adalah nilai ketersediaan sumber daya $(R)$ operasi bedah $\mathrm{X}$ yang dipengaruhi oleh perubahan jadwal operasi Y. Ruang operasi $(O R)$, perangkat bedah $(V)$, dokter anastesi $(A)$, dokter bedah $(S)$ dan perawat $(N)$ termasuk kategori sumber daya $(R)$ sehingga $R=\{O R, V, A, S, N\}$. Nilai $A_{X}$ didapatkan dari hasil perhitungan pada persamaan (2)

$$
A_{X}=\sum_{1}^{n}\left(i_{n} \times w_{n} \times T_{n}\right), T_{n}=\frac{Y_{E}-X_{S}}{D_{X}}
$$

Nilai ketersediaan sumber daya $\left(A_{X}\right)$ dihasilkan dari perkalian nilai index $i$, nilai berat (weight values) $w$, dan waktu keterlambatan $T$ untuk $1 \leq R \leq n$ dimana $n$ adalah jumlah sumber daya. $T_{n}$ adalah waktu keterlambatan sumber daya pada operasi bedah $\mathrm{X}$ yang disebabkan perubahan jadwal operasi bedah Y. Waktu keterlambatan adalah selisih waktu berakhirnya jadwal operasi bedah $\mathrm{Y}\left(Y_{E}\right)$ dan dimulainya jadwal operasi bedah $\mathrm{X}$ yang kemudian dibagi dengan durasi operasi bedah X. Jika nilai $T_{n} \leq 0$ maka tidak ada konflik sumber daya pada operasi akibat perubahan operasi Y, sebaliknya terjadi konflik jika nilai $T_{n}>0$.

Index $i$ adalah nilai konflik penggunaan sumber daya di operasi lain. $w$ adalah nilai pentingnya penggunaan sumber daya di operasi X. Pada kasus ini, pembagian konflik dibagi menjadi dua yaitu tidak terjadi konflik jika sumber daya tidak beririsan dengan jadwal operasi yang lain dengan nilai $i=0$. Terjadi konflik jika sumber daya beririsan dengan jadwal operasi yang lain dengan nilai $i=1$. Semua sumber daya yang terlibat pada operasi memiliki level yang sama dalam pentingnya sumber daya dalam pelaksanaan operasi, sehingga nilai $w=1$. Baik untuk operasi elektif maupun emergency, kondisi pasien merupakan prioritas pertama sehingga nilai $C_{P}=0$. Kedua belah pihak dianggap memberikan persetujuan dalam pelaksanaan operasi baik operasi elektif maupun emergency sehingga nilai $C_{O}=0$.

\subsection{Rule-based}

Rule-based merupakan sebuah representasi pengetahuan dalam bentuk IF-THEN kondisi (Belavkin 2010). Rules adalah sebuah simbol yang terdiri dari bagian kiri (left hand side) dan bagian kanan (right hand side) (Buchanan \& Shortliffe 1984). Left Hand Side berada di bagian IF yang memiliki fungsi untuk menyocokkan rule yang sesuai dengan data Facts. Tindakan atau aksi yang dilakukan berdasarkan hasil kesesuaian rule berada di bagian kanan (Right Hand Side) yaitu THEN. Berikut bentuk dari sebuah rule

IF < conditions > THEN <action>

Ketika kondisi sebuah rule terpenuhi, maka rule dikatakan dalam keadaan "Fire" dan sebuah aksi akan dieksekusi. Forward Chaining merupakan salah satu metode reasoning pada rule-based yang berorientasi pada kesesuaian rules dengan data "Facts" yang diberikan (Kerber 2004).

\section{Metodologi}

\subsection{Penyusunan Data Penjadwalan}

Struktur data penjadwalan dibentuk berdasarkan hasil wawancara kepada dua orang narasumber. Narasumber merupakan seorang dokter bedah umum dan dokter obgyn yang berpraktek di rumah sakit swasta Jakarta, dan telah melakukan lebih dari 40 kali operasi dalam satu tahun. Empat pertanyaan diajukan kepada nara sumber (Tabel 2).

Tabel 2. Daftar Pertanyaan

\begin{tabular}{lll}
\hline \hline No & Komponen \\
\hline \hline 1 & $\begin{array}{l}\text { Informasi apa saja yang dibutuhkan } \\
\text { ketika membuat jadwal operasi bedah }\end{array}$ \\
\hline 2 & $\begin{array}{l}\text { Siapa saja yang terlibat dalam sebuah } \\
\text { operasi bedah }\end{array}$ \\
\hline 3 & $\begin{array}{l}\text { Bagaimana pembagian kamar operasi di } \\
\text { sebuah rumah sakit }\end{array}$ \\
\hline 4 & $\begin{array}{l}\text { Bagaimana menentukan perubahan } \\
\text { jadwal operasi bedah }\end{array}$ \\
\hline
\end{tabular}

Tabel 3 menunjukkan komponen data penjadwalan berdasarkan hasil wawancara.

\subsection{Rancangan dan Implementasi}

Algoritma Resilience dan Rule-Based diterapkan pada sistem penjadwalan operasi bedah elektif.

\subsubsection{Rancangan Algoritma Resilience}

Gambar 1 menunjukkan flowchart dari sistem 
penjadwalan yang menerapkan algoritma resilience. Perombakan jadwal dilakukan jika terjadi emergency case yang membutuhkan tindakan operasi, atau perubahan jadwal operasi elektif di hari-H operasi. Nilai $E_{Y}$ dihitung untuk melihat efek resiko atas pengaturan jadwal operasi bedah Y. Jika nilai $E_{Y}>0$, maka jadwal operasi bedah $Y$ tidak dapat dipindahkan karena memiliki resiko yang tinggi. Jika $E_{Y} \leq 0$ maka perpindahan jadwal dapat dilakukan, dan data penjadwalan yang terdapat dalam basis data akan diperbarui.

Tabel 3. Komponen Data

\begin{tabular}{ll}
\hline Komponen & Keterangan \\
\hline Duration & Durasi Operasi \\
$\begin{array}{l}\text { Start Time/ Waktu } \\
\text { Mulai }\end{array}$ & Jam Operasi \\
Room & Kamar Operasi \\
Patient Name & Nama Pasien \\
Condition & Status Kesiapan Operasi \\
Procedure & Prosedur Operasi \\
Diagnosis & Diagnosa Penyakit \\
\hline Registration Number & Nomor Registrasi \\
Surgeon & Dokter Bedah \\
Anesthetist & Dokter Anastesi \\
Nurse & Perawat \\
\hline
\end{tabular}

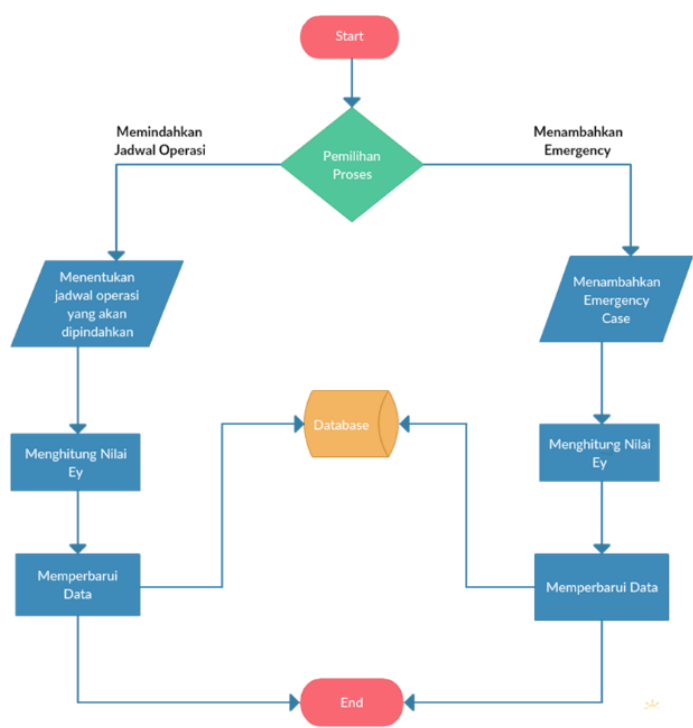

Gambar 1. Flowchart Aplikasi Menggunakan Resilience

\subsubsection{Rancangan Algoritma Rule-Based}

Terdapat dua himpunan rules yang mengatur perubahan jadwal operasi bedah. Himpulan rules 1 terdiri dari rule-rule yang berfungsi untuk menentukan jadwal operasi elektif yang akan dipindahkan (Gambar 2). Penambahan jadwal operasi bedah untuk emergency case diatur oleh himpunan rules 2 (Gambar 3). Himpuran rules 1 terdiri dari 5 rule (Tabel 4), sedangkan himpunan rules 2 terdapat 16 rule. Start time dan end time jadwal operasi menyatakan jadwal mulai dan berakhirnya operasi bedah di satu ruangan operasi. Start time dan end time jadwal SDM adalah jadwal mulai dan berakhirnya tugas sumber daya manusia dalam sebuah operasi bedah.

Tabel 4. Rincian Himpunan Rules 1

\begin{tabular}{|c|c|c|c|}
\hline $\begin{array}{l}\text { Nomor } \\
\text { Rule } \\
\end{array}$ & Kondisi (IF) & & Aksi (THEN) \\
\hline $\mathrm{R} 1.1$ & $\begin{array}{l}\text { (start time jadwal operasi } \\
=\text { beririsan) }\end{array}$ & $\Rightarrow$ & $\begin{array}{l}\text { Tidak dapat } \\
\text { memindahkan } \\
\text { jadwal operasi }\end{array}$ \\
\hline R1.2 & $\begin{array}{l}\text { (start time jadwal operasi }= \\
\text { tidak beririsan }) \wedge \text { (end time } \\
\text { jadwal operasi }=\text { beririsan })\end{array}$ & $\Rightarrow>$ & $\begin{array}{l}\text { Tidak dapat } \\
\text { memindahkan } \\
\text { jadwal operasi }\end{array}$ \\
\hline R1.3 & $\begin{array}{l}\text { (start time jadwal operasi }= \\
\text { tidak beririsan) } \wedge \\
(\text { end time jadwal operasi }= \\
\text { tidak beririsan })^{\wedge} \\
\text { (start time jadwal sdm }= \\
\text { beririsan) }\end{array}$ & $=>$ & $\begin{array}{l}\text { Tidak dapat } \\
\text { memindahkan } \\
\text { jadwal operasi }\end{array}$ \\
\hline R1.4 & $\begin{array}{l}\text { (start time jadwal operasi }= \\
\text { tidak beririsan) } \wedge \\
(\text { end time jadwal operasi }= \\
\text { tidak beririsan })^{\wedge} \\
(\text { start time jadwal sdm }=\text { tidak } \\
\text { beririsan) } \wedge \\
(\text { end time jadwal sdm }= \\
\text { beririsan) }\end{array}$ & $\Rightarrow$ & $\begin{array}{l}\text { Tidak dapat } \\
\text { memindahkan } \\
\text { jadwal operasi }\end{array}$ \\
\hline$\overline{\mathrm{R} 1.5}$ & $\begin{array}{l}\text { (start time jadwal operasi }= \\
\text { tidak beririsan) } \wedge \\
(\text { end time jadwal operasi }= \\
\text { tidak beririsan) } \wedge \\
(\text { start time jadwal sdm }=\text { tidak } \\
\text { beririsan) } \wedge \\
(\text { end time jadwal sdm }=\text { tidak } \\
\text { beririsan) }\end{array}$ & $\Rightarrow>$ & $\begin{array}{l}\text { Memindahkan } \\
\text { jadwal operasi }\end{array}$ \\
\hline
\end{tabular}

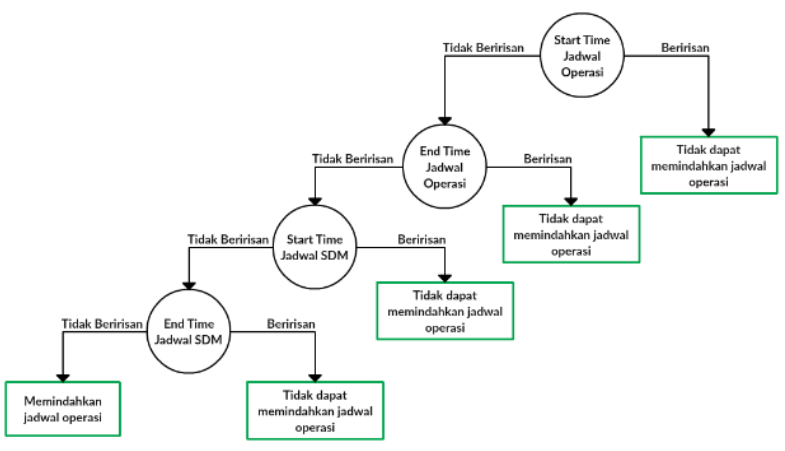

Gambar 2. Struktur Bagan Himpunan Rules 1

\subsection{Verifikasi}

Pengujian kinerja dua algoritma dilakukan untuk membuktikan keberhasilan algoritma dalam menangani perubahan jadwal operasi bedah. Terdapat dua skenario utama untuk masingmasing aplikasi yaitu skenario pengujian pemindahan jadwal operasi bedah elektif 
(Skenario E) dan penambahan kasus Emergency (Skenario ER) di hari-H operasi (Tabel 5 dan 6).

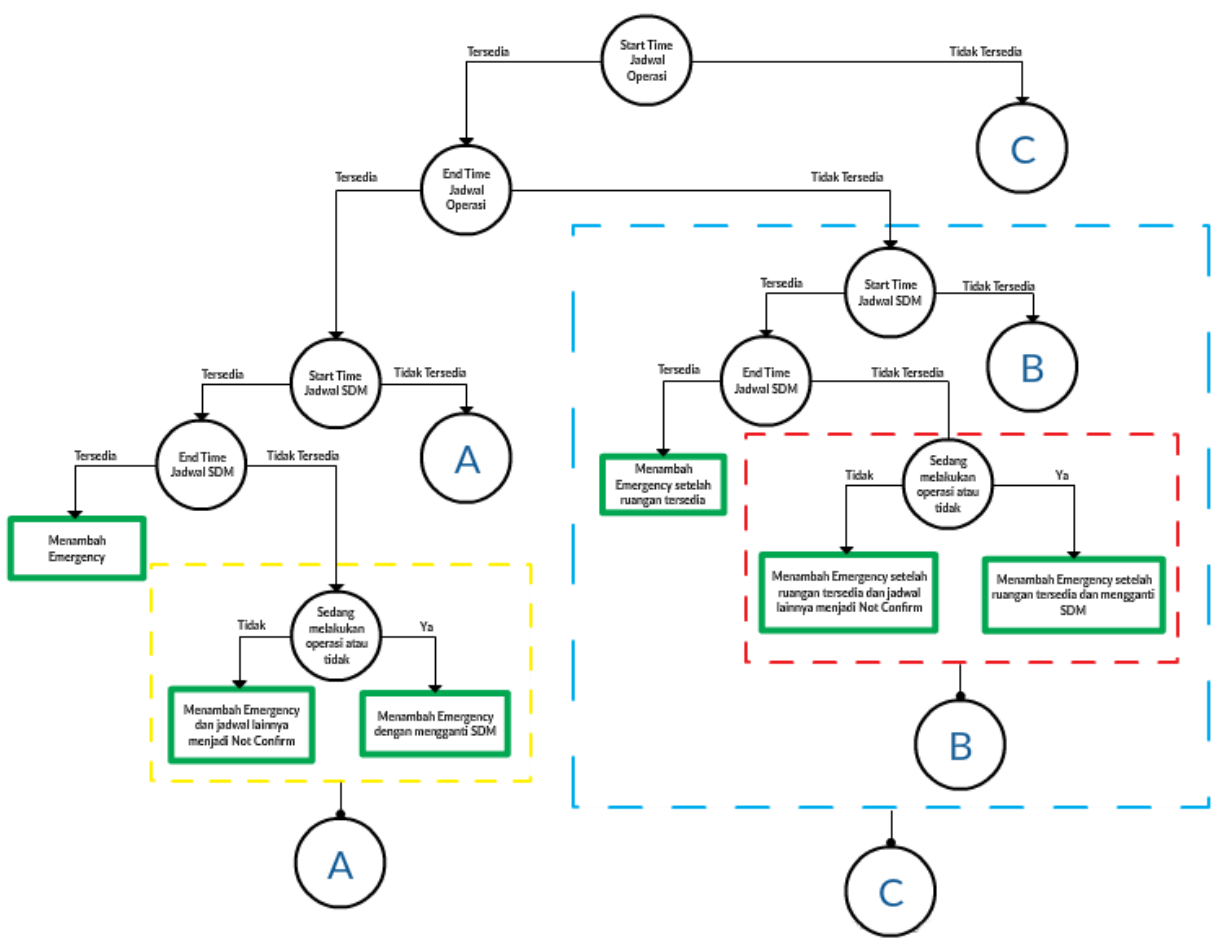

Gambar 3. Struktur Bagan Himpunan Rules 2

Table 5. Skenario Pengujian Pemindahan Jadwal Operasi Elektif di hari-H operasi

\section{Skenario Pengujian}

Skenario E1

Jadwal operasi Y dimajukan, dan tidak beririsan dengan jadwal operasi sebelum atau sesudahnya di ruang operasi yang sama

Skenario E2

Jadwal operasi Y dimajukan, dan beririsan dengan jadwal operasi sebelum atau sesudahnya di ruang operasi yang sama

Skenario E3

Jadwal operasi Y dimundurkan, dan tidak beririsan dengan jadwal operasi sesudahnya di ruang operasi yang sama

Skenario E4

Jadwal operasi Y dimundurkan, dan beririsan dengan jadwal operasi sesudahnya di ruang operasi yang sama

Skenario E5

Durasi pelaksanaan operasi Y diperpanjang, dan tidak beririsan dengan jadwal operasi sesudahnya di ruang operasi yang sama

Skenario E6

Durasi pelaksanaan operasi Y diperpanjang, dan beririsan dengan jadwal operasi sesudahnya di ruang operasi yang sama

Skenario E7

Jadwal operasi Y dimajukan, dan jadwal SDM tidak beririsan dengan operasi sebelum atau sesudahnya

Skenario E8

Jadwal operasi Y dimajukan, dan jadwal SDM beririsan dengan operasi sebelum atau sesudahnya

Skenario E9

Jadwal operasi Y dimundurkan, dan jadwal SDM tidak beririsan dengan operasi sesudahnya
Skenario E10

Jadwal operasi Y dimundurkan, dan jadwal SDM beririsan dengan operasi sesudahnya

Skenario E11

Durasi pelaksanaan operasi Y diperpanjang, dan jadwal SDM tidak beririsan dengan operasi sesudahnya

Skenario E12

Durasi pelaksanaan operasi Y diperpanjang, dan jadwal SDM beririsan dengan operasi sesudahnya

Table 6. Skenario Pengujian Penambahan Kasus Emergency di hari-H operasi

\begin{tabular}{l} 
Skenario Pengujian \\
\hline Skenario ERI \\
Menambahkan kasus Emergency, dan beririsan dengan
\end{tabular}

Menambahkan kasus Emergency, dan beririsan dengan
jadwal operasi sebelumnya yang berstatus belum melaksanakan operasi di ruang operasi yang sama

Skenario ER 2

Menambahkan kasus Emergency, dan beririsan dengan jadwal operasi sesudahnya yang berstatus belum melaksanakan operasi di ruang operasi yang sama

Skenario ER3

Menambahkan kasus Emergency, dan beririsan dengan jadwal operasi sebelum dan sesudahnya yang berstatus belum melaksanakan operasi di ruang operasi yang sama

Skenario ER4

Menambahkan kasus Emergency, jadwal SDM beririsan dengan operasi sebelumnya yang berstatus belum melaksanakan operasi

Skenario ER5

Menambahkan kasus Emergency, jadwal SDM beririsan dengan operasi sesudahnya yang berstatus belum melaksanakan operasi 
Skenario ER6

Menambahkan kasus Emergency, jadwal SDM beririsan dengan operasi sebelum dan sesudahnya yang berstatus belum melaksanakan operasi

Skenario ER7

Menambahkan kasus Emergency, dan beririsan dengan jadwal operasi sebelumnya yang sedang melakukan operasi di ruang operasi yang sama

Skenario ER8

Menambahkan kasus Emergency, dan SDM sedang bertugas melaksanakan operasi

\section{Hasil dan Analisis}

\subsection{Sistem dengan metode Resilience Concept}

Hasil pengimplementasian resilience concept dalam mengatur penjadwalan ruang operasi berbentuk sebuah aplikasi desktop.

Uncertainty case pada penelitian adalah penambahan kasus gawat darurat dan perubahan jadwal operasi bedah elektif di hari-H operasi. Oleh karena itu, terdapat dua menu utama pada aplikasi, yaitu Schedule dan Add Emergency dengan penjelasan sebagai berikut

\section{Menu Schedule}

Menu yang dapat memindahkan atau mengatur penjadwalan ruang operasi jika terjadi perubahan jadwal pada hari-H operasi.

Gambar 4 merupakan tampilan dari menu Schedule yang terdiri dari

a. Room

Room (ruangan) merupakan nomor ruangan operasi bedah yang tersedia pada sebuah Rumah Sakit.

b. Department

Bagian ini berisi department yang memiliki ruang operasi.

c. Time

Time merupakan waktu pelaksanaan operasi, dan digambarkan dalam bentuk persegi panjang yang memiliki warna (Gambar 5). Jadwal operasi mengikuti jam kerja pada umumnya yaitu jam 08:00 sampai dengan 17:00.

\section{d. Operation}

Operation merupakan komponen yang mengatur perpindahan jadwal operasi. Pada komponen ini pengguna dapat memindahkan jadwal operasi yang telah tersedia menuju jam yang diinginkan. Inputan berupa ruangan asal, jam operasi yang akan dipindahkan, department asal, ruangan dan jam tujuan operasi (Gambar 6).

e. Not Confirmed

Not Confirmed merupakan notifikasi yang memberitahukan kepada pengguna tentang operasi yang belum dapat dilaksanakan (Gambar 7).

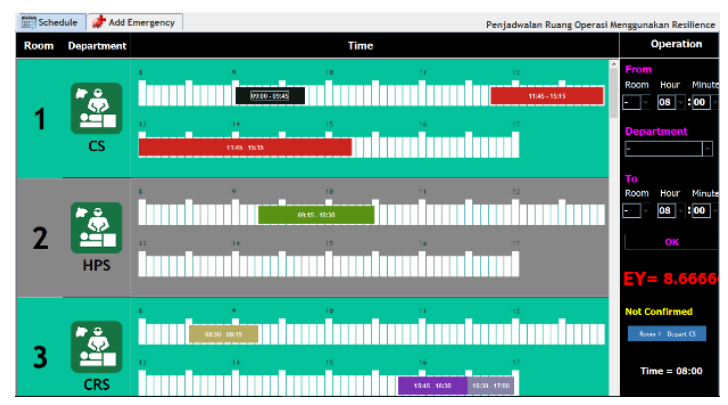

Gambar 4. Tampilan Menu Schedule

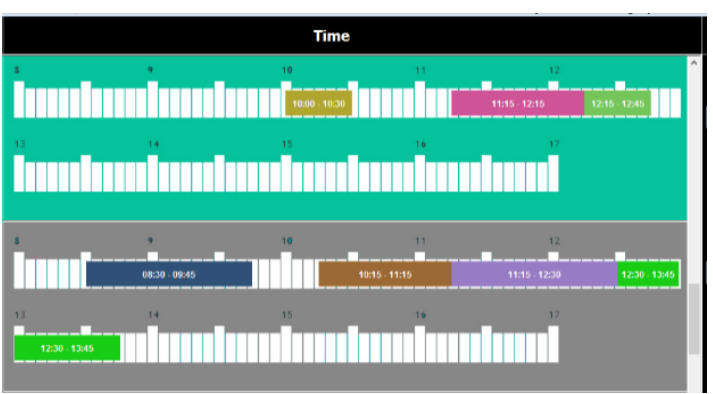

Gambar 5 - Tampilan Pada Bagian Time

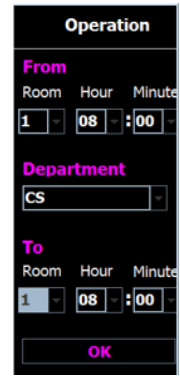

Gambar 6 - Tampilan Operation

f. Nilai $E_{Y}$

Penentu diperbolehkannya sebuah jadwal operasi bedah untuk dirubah adalah nilai $E_{Y}$ (Gambar 8). Nilai $E_{Y}$ adalah nilai resiko yang dihasilkan pada perubahan jadwal sebuah operasi bedah. Jika nilai $E_{Y}$ lebih besar sama dengan $0 \quad\left(E_{Y}>0\right)$, maka jadwal ruang operasi tidak dapat di pindahkan. Jika sebaliknya, maka operasi dapat dipindahkan.

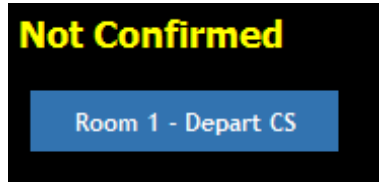

Gambar 7. Tampilan Not Confirmed 


\section{$\underline{Y}=8.6666$}

Gambar 8. Tampilan Nilai Ey

g. Alert

Alert merupakan penanda sukses atau tidaknya jadwal operasi dipindahkan. Warna hijau menandakan berhasilnya sebuah jadwal operasi dipindahkan (Gambar 9), sedangkan warna merah menandakan terjadi irisan atau bentrokan dengan jadwal operasi yang lain (Gambar 10).

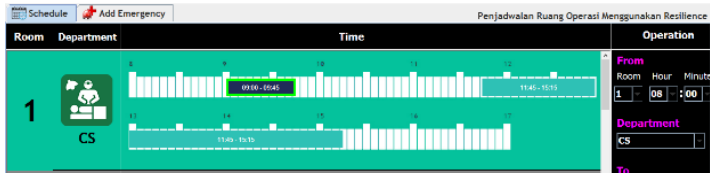

Gambar 9. Alert Berwarna Hijau

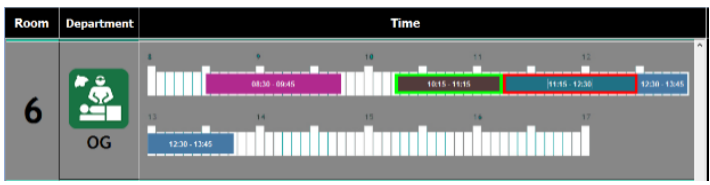

Gambar 10. Alert Berwarna Merah

\section{Menu Add Emergency}

Sebuah menu yang berfungsi untuk menambah jadwal operasi untuk pasien gawat darurat (Gambar 11). Data yang perlu ditambahkan dalam menambahkan jadwal operasi antara lain departemen pelaksana operasi bedah, jam mulai operasi, durasi operasi, nama pasien, jenis kelamin/usia, nomor ward, konfirmasi pelaksanaan, prosedur, diagnosis, wilayah operasi yaitu daerah bagian tubuh yang akan dioperasi, tipe anestesi, tindakan khusus, asuransi, nomor registrasi, dokter bedah, dokter anastesi dan perawat.

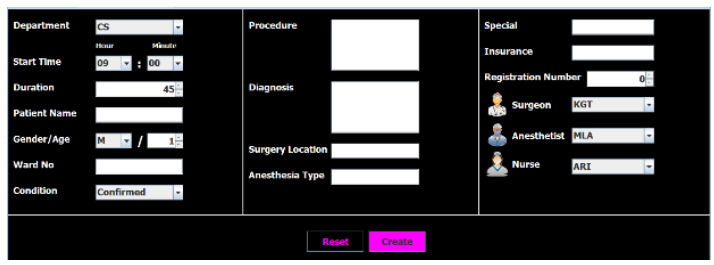

Gambar 11. Tampilan Add Emergency

\subsection{Sistem dengan metode Rule-Based}

Antarmuka pada sistem penjadwalan dengan metode Rule-Based tidak berbeda dengan metode Resilience Concept. Perbedaan kedua sistem terdapat dari proses perpindahan atau perubahan jadwal operasi.

\subsection{Analisis}

Tabel 7 menunjukkan persentase keberhasilan dari kedua algoritma diukur dari hasil pengeksekusian setiap item skenario pengujian. Kedua algoritma menunjukkan kinerja yang baik dengan persentase keberhasilan sebesar $100 \%$ untuk skenario E dan ER. Walaupun hasilnya baik, namun kedua algoritma belum dapat memberikan prioritas atas pilihan perubahan jadwal yang memberikan resiko terkecil.

Pada Rule-Based, pengelolaan perubahan jadwal hanya mempertimbangkan kondisi pasien dan konflik pada sumber daya. Gawat atau tidaknya kondisi pasien serta tersedianya SDM adalah aturan dipindahkannya sebuah jadwal operasi. Berbeda dengan Resilience Concept yang dapat menghitung nilai resiko yang ditimbulkan akibat perubahan jadwal operasi. Akan tetapi, algoritma Resilience Concept belum dapat memenuhi tujuannya yaitu memberikan nilai resiko berdasarkan tingkatan resikonya. Nilai $E_{Y}=0$ membuat rumus resilience concept tidak dapat memberikan keragaman nilai resiko atas perubahan jadwal operasi. Penyebabnya adalah pemberian nilai index $i=0$ untuk sumber daya yang tidak beririsan dengan operasi lain.

Penetapan nilai index $i=0$ harus dilakukan agar dapat memenuhi kondisi dimajukannya jadwal pelaksanaan operasi $\mathrm{Y}$ tetapi tidak mengakibatkan irisan dengan operasi sebelumnya yaitu operasi X. Bergesernya jadwal operasi menjadi lebih awal, membuat nilai $T_{n}$ menjadi lebih besar dari $0\left(T_{n}>0\right)$. Nilai ini menunjukkan terjadi keterlambatan pada sumber daya operasi bedah $\mathrm{X}$ akibat perpindahan jadwal operasi $\mathrm{Y}$, walaupun pada kenyataannya, operasi $X$ tidak beririsan dengan operasi Y. Oleh karena itu, penentapan nilai index $i=0$ harus dilakukan untuk membuat sumber daya $\mathrm{X}$ menjadi tersedia. Ketersediaan sumber daya $X$ membuat tidak adanya resiko yang ditimbulkan atas perubahan jadwal operasi $\mathrm{Y}\left(E_{Y}=0\right)$.

Table 7. Hasil Percobaan Sistem

\begin{tabular}{ccc}
\hline Tipe Skenario & Algoritma & $\begin{array}{c}\text { Persentase } \\
\text { Keberhasilan (\%) }\end{array}$ \\
\hline Skenario E & $\begin{array}{c}\text { Resilience } \\
\text { Concept } \\
\text { Rule-Based } \\
\text { Skenario ER }\end{array}$ & 100 \\
& $\begin{array}{c}\text { Resilience } \\
\text { Concept } \\
\text { Rule-Based }\end{array}$ & 100 \\
& & 100 \\
\hline
\end{tabular}

\section{Kesimpulan}

Faktor-faktor yang menentukan penjadwalan kegiatan operasi bedah untuk uncertainty case adalah kondisi pasien, ketersediaan sumber daya, 
dan persetujuan pelaksanaan operasi dari pihak pasien dan rumah sakit. Uncertainty case adalah kasus operasi bedah yang jadwalnya tidak dapat diprediksi. Kasus gawat darurat dan keterlambatan pelaksanaan atau penyelesaian tindakan operasi elektif adalah dua kasus yang tergolong uncertainty case. Dua model sistem penjadwalan operasi bedah untuk uncertainty case diimplementasikan dan dibandingkan. Sistem penjadwalan dengan metode Rule-Based dan Resilience Concept memberikan hasil kinerja yang baik. Persentase kesuksesan kedua algoritma dalam mengeksekusi dua skenario pengujian sebesar $100 \%$. Dua skenario pengujian antara lain perubahan jadwal operasi elektif, dan penanganan jadwal untuk kasus gawat darurat.

Namun, Rule-Based dan Resilience Concept tidak dapat memberikan prioritas pilihan berdasarkan tingkatan resiko. Perpindahan jadwal operasi Y menjadi lebih awal, dan tidak beririsan dengan operasi sebelumnya (X) membuat nilai keterlambatan sumber daya operasi $\mathrm{X}$ menjadi tidak akurat yaitu $T_{n}>0$. Nilai $T_{n}$ menunjukkan terjadinya keterlambatan sumber daya $\mathrm{X}$ akibat perubahan jadwal operasi Y. Hal ini membuat perubahan jadwal operasi $\mathrm{Y}$ memberikan resiko pada jadwal operasi lain $\left(E_{Y}>0\right)$. Untuk membuat perpindahan jadwal tidak beresiko, nilai index $i$ ditentukan menjadi $i=0$. Nilai ini menandakan tidak terjadinya konflik sumber daya antara operasi Y dengan operasi X. Penetapan nilai $i=0$, mempengaruhi nilai ketersediaan sumber daya $\left(A_{X}\right)$ yang berdampak pada nilai resiko $E_{Y}$ menjadi $E_{Y}=0$ untuk setiap kasus perubahan jadwal operasi yang tidak beririsan. Hal ini membuat resilience concept belum dapat memberikan nilai resiko perubahan jadwal operasi $\mathrm{Y}$ berdasarkan tingkat resikonya.

Oleh karena itu, perhitungan nilai $T_{n}$ perlu dikaji ulang dengan mempertimbangkan kasus pergeseran jadwal operasi menjadi lebih awal yang tidak beririsan dengan jadwal operasi sebelumnya. Pemberian nilai $i$ juga harus diragamkan berdasarkan tingkat konfliknya. Pengujian langsung ke rumah sakit juga perlu dilakukan untuk menilai keefektikan sistem dalam menangani penjadwalan operasi bedah di dunia nyata.

\section{Acknowledgement}

Penelitian ini didanai oleh Universitas YARSI melalui pemberian dana dengan skema Hibah Internal.

\section{Referensi}

Belavkin, R V 2010, BIS3226 AI Techniques in
Information Management, week 3: Logic and Rule-Based Reasoning, pdf, viewed 1 November 2016, http://www.eis.mdx.ac.uk/staffpages/rvb/teach ing/BIS3226/hand03.pdf.

Buchanan, B G \& Shortliffe, E H 1984, RuleBased Expert System: The MYCIN Experiments of the Standford Heuristic Programming Project, Addison-Wesley, Stanford.

Carthey, J, De Leval, M R \& Reason, J T 2001, 'Institutional resilience in healthcare systems', International Journal for Quality in Health Care, vol. 10, no. 1 , pp. 29-32.

Dexter, F, Willemsen-Dunlap, A \& Lee, J D 2007 , 'Operating room managerial decision-making on the day of surgery with and without computer recommendations and status displays', Anesth. Analg., vol. 105, no. 2, pp. 419-429.

Hans, E, Wullink, G, Houdenhoven, M V \& Kazemier, G 2008, 'Robust surgery loading', European Journal of Operational Research, vol. 185 , no. 3 , pp. 1038-1050.

Haraty, R A 2016, 'Innovative Mobile EHealthcare Systems: A New Rule-Based Cache Replacement Strategy Using Least Profit Values', Mobile Information Systems, vol. 63, pp. 1-9.

Hollnagel, E, Woods, D D \& Leveson, N 2006, Resilience engineering: Concepts and precepts, Ashgate Publishing Ltd, Surrey, United Kingdom.

Jeffcott, S A, Ibrahim, J E \& Cameron, P A 2009, "Resilience in healthcare and clinical handover", Quality and Safety in Health Care, vol.18, no. 4, pp. 256-260.

Kerber, M 2004, Introduction to AI, week 2: Expert Systems, viewed 1 november 2016, http://www.cs.bham.ac.uk/ mmk/Teaching/AI /12.html.

Lamiri, M, Xiea, X, Dolguia, A \& Grimauda, F 2008a, "Stochastic model for operating room planning with elective and emergency demand for surgery", European Journal of Operational Research, vol. 185, no. 3, pp. 1026-1037.

Saraiva, R M, Bezerra, J, Perkusich, M, Almeida, H \& Siebra, C 2015, 'A Hybrid Approach Using Case-Based Reasoning and Rule-Based Reasoning to Support Cancer Diagnosis: A Pilot Study', Proceedings of the 15th World Congress on Health and Biomedical Informatics, pp. 862 - 866.

Wiyartanti, L, Woong, M, Chung, D \& Kwan , J 2015, 'Managing Uncertainties in the Surgical Scheduling', Proceedings of Medical Informatics Europe (MIE), pp. 384-388. 